\title{
JOHANNES LEIMENA DALAM KESEHATAN IBU DAN ANAK DI INDONESIA (1946-1956)
}

\author{
Oleh: \\ Rella Astiannis dan Didin Saripudin ${ }^{1}$
}

\begin{abstract}
Mother and child welfare are very important in every country and one of the most important issues that should have an attention from the Minister of Health. Because it will affect a country's progress and resilience. To increasing mother and child welfare, a comprehensive act such as economic, social, and health itself need to be implemented. For a newly independent state, that was a difficult thing to be done. Likewise, Indonesia after gained independence which also dealt with difficulties in improving their society health particularly mother and child health where at that time mortality were very high. Coupled with Indonesia which was confronted the revolutionary era (1945-1956) after gained its independence. Dr Johannes Leimena as a Minister of Health of the Republic of Indonesia from 1946 to 1956 was the one who has responsibility for public health in that period. This research was intended to analyse on increasing mother and child's programs under Johannes Leimena era which referred to historical research methods such as heuristic, criticism, and historiography. Based on the result, in19401950 Indonesia has a low rate of population growth and one of them was due to the high rate of maternal and child mortality. At that time, Indonesia experienced an economic crisis that must strive to provide primary health care for mothers and children in Indonesia. So in 1951, Dr Johannes Leimena established BKIA (Balai Kesejahteraan Ibu dan Anak or Mother and Child Welfare Center) as a solution to these problems. $B K I A$ is a regional health service centre including providing counselling to mothers and children. In its implementation in Indonesia, the BKIA assisted by UNICEF as an international child protection institution, as well as the government and the community who also participated in succeeded in the program. With its consistency, BKIA as the frontline for maternal and child health services that also served public health can reduce population's mortality rates in Indonesia and even gave an impact on increasing public awareness of the importance of maintaining health.
\end{abstract}

Keywords: Dr. Johannes Leimena, Maternal and Child Health, Mortality, Public Health

${ }^{1}$ Rella Astiannis adalah mahasiswa pada Departemen Pendidikan Sejarah FPIPS UPI, Didin Saripudin adalah dosen pembimbing I. Penulis dapat dihubungi di alamat email : rella.astiannis@gmail.com 


\section{PENDAHULUAN}

Peningkatan kesehatan ibu dan anak merupakan upaya pelayanan dan pemeliharaan ibu hamil, ibu bersalin, bayi, anak balita, serta anak prasekolah. Layanan tersebut perlu ada di dalam suatu negara atas dasar keutamaan hak asasi manusia juga atas dasar kepentingan negara dalam upaya menjamin keberlangsungan perikehidupan dalam hal regenerasi bangsa. Indonesia semasa kependudukan Belanda maupun Jepang juga tak luput dari upaya tersebut tentunya dengan pelaksanaan yang berbeda dan atas dasar kepentingan kolonialisme maupun imperialisme.

Pada tahun 1808, layanan kesehatan pada masa Belanda hanya diperuntukkan bagi kalangan militer maupun kalangan elit kolonial Belanda. Satu tahun berikutnya yaitu 1809, layanan kesehatan sipil didirkan di tiga kota besar yaitu Batavia, Semarang, dan Surabaya. Perhatian layanan kesehatan bagi masyarakat pribumi baru tergambar pada tahun 1851 dengan dibukanya Sekolah Dokter Jawa disertai dengan program pendidikan bidan di Indonesia (Departemen Kesehatan RI, 2009b, hlm. 29-46). Namun kenyataanya, subsidi dari pemerintah Belanda terhadap rumah sakit Hindia Belanda, rumah sakit swasta, rumah sakit pembantu, rumah sakit daerah tidak memperoleh subsidi yang merata. Subsidi tersebut dapat berupa dana kas, obat-obatan, maupun gaji dokter sehingga seringkali pasien harus membayar biaya layanan kesehatan yang diberikan (Baha'Uddin, 2006, hlm. 7). Maka, sebenarnya Pemerintah Hindia Belanda tidak dapat menjamin layanan kesehatan yang merata bagi masyarakat pribumi termasuk dalam hal meningkatkan kesehatan ibu dan anak.

Sementara pada masa pendudukan Jepang berita-berita mengenai layanan kesehatan bagi masyarakat pribumi justru mengalami penurunan. Jepang hanya mementingkan kemenangan perangnya di Asia sehingga dengan mudahnya merebut fasilitas-fasilitas umum seperti rumah sakit untuk keperluan menyimpan senjata. Kondisi kesehatan masyarakat Indonesia pada masa kependudukan Jepang digambarkan dengan merebaknya krisis pangan yang hebat sehingga banyak terjadi busung lapar dibeberapa daerah. Daerah yang paling banyak menderita busung lapar ialah Bojonegoro. Krisis pangan yang terjadi pada saat itu akibat dari 50\% hasil panen rakyat Indonesia harus disumbangkan kepada tentara Jepang. Kemudian, kebutuhan makanan masyarakat pribumi sangat diperhitungkan pada masa itu yaitu dengan membatasi asupan kalori masyarakat Indonesia hanya 1000 kalori sehari (Departemen Kesehatan RI, 2009b, hlm. 71-72). Padahal sebetulnya asupan kalori yang dibutuhkan dalam sehari umumnya 2.125-2.250 kalori untuk wanita dewasa dan 2.625-2.725 kalori untuk pria dewasa. Berdasarkan pemaparan tersebut, maka dalam kondisi krisis pangan yang banyak terjadi di Indonesia, Jepang sama sekali tidak memberikan perhatian terhadap kesehatan ibu dan anak.

Setelah Indonesia merdeka, rupanya upaya peningkatan kesehatan ibu dan anak juga mengalami hambatan. Perjuangan di masa revolusi menyebabkan pemerintah Republik Indonesia lebih mengutamakan upaya perlawanan maupun pertahanan untuk menjaga kedaulatan Republik 
Indonesia, baik secara fisik maupun non fisik seperti diplomasi. Sementara Indonesia sebagai suatu negara yang baru merdeka yang tidak semata-mata berjuang menghadapi kenyataan untuk melawan Belanda yang dibonceng Inggris tetapi rakyat Indonesia memerlukan perhatian atas kebutuhannya sebagai warga negara Indonesia yang harus diperhatikan oleh pemerintah dan salah satunya ialah layanan kesehatan ibu dan anak yang perlu segera ditangani. Lalu bagaimanakah pemerintah, dalam hal ini Menteri Kesehatan Republik Indonesia saat itu menangani kondisi kesehatan ibu dan anak Indonesia?

Menteri Kesehatan Republik Indonesia pada tahun 1945 ialah Dr. Boentaran Martoatmodjo, namun tidak sampai satu tahun menjabat sebagai Menteri Kesehatan RI kemudian Dr. Boentaran Martoatmodjo digantikan oleh dr. Darma Setiawan, dr. Darma Setiawan juga tidak lama menjabat sebagai Menteri Kesehatan hingga akhirnya digantikan oleh Dr. Johannes Leimena yang sebelumnya menjabat sebagai Menteri Muda Kesehatan pada tahun 1946 dan mengakhiri amanahnya sebagai Menteri Kesehatan RI pada tahun 1956 (Departemen Kesehatan RI, 2009a, hlm.15). Dari kiprah Dr. Johannes Leimena inilah peneliti memperoleh informasi mengenai kontribusinya dalam meningkatkan kesehatan ibu dan anak di Indonesia.

Selama Dr. Johannes Leimena menjabat sebagai Menteri Kesehatan RI tahun 1946-1956 beliau dihadapkan pada masa yang sulit, dimana dari tahun 1945 sampai dengan tahun 1949 dikenal sebagai masa revolusi dan dari tahun 1950 sampai dengan 1957 dikenal sebagai masa Demokrasi Liberal. Kesulitan dan ketidakstabilan pada masa itu berdampak pada bidang politik, sosial, ekonomi termasuk kesehatan masyarakat Indonesia. Tahun 1940-1950 Indonesia mengalami laju pertumbuhan penduduk yang lambat akibat tingginya mortalitas penduduk Indonesia. Tingginya angka mortalitas tersebut disebabkan oleh beberapa hal diantaranya berkembangnya wabah penyakit, krisis pangan, dan rendahnya layanan kesehatan ibu dan anak.

Permasalahan mengenai tingginya angka mortalitas ibu dan anak perlu ditangani secara serius. Sebab hal tersebut dapat berdampak kepada eksistensi ataupun ketahanan negara Indonesia. Maka melalui penelitian ini, peneliti memfokuskan permasalahan kepada bagaimanaDr.Johannes Leimenaberupaya untuk meningkatkan kesejahteraan ibu dan anak. Adapun tujuan dari penelitian ini ialah untuk mengidentifikasi program dan ketercapaian dari program yang ditetapkan dalam meningkatkan kesehatan ibu dan anak di Indonesia pada masa kepemimpinan Dr. Johannes Leimena.

Penulisan artikel ini menggunakan konsep Dr. Johannes Leimena, kesehatan masyarakat, mortalitas, dan BKIA (Balai Kesejahteraan Ibu dan Anak). Adapun penjelasan peneliti menggunakan konsepkonsep tersebut ialah: pertama, konsep Dr. Johannes Leimena dipilih peneliti untuk mengkaji kontribusi Dr. Johannes Leimena dalam meningkatkan kesehatan ibu dan anak selama menjabat sebagai Menteri Kesehatan Republik Indonesia. Kedua, konsep kesehatan masyarakat digunakan untuk memberi gambaran prinsip kesehatan yang tidak hanya ditunjang dari segi ilmu dan teknologi melainkan dari segi sosial juga. Ketiga, 
konsep mortalitas yang menggambarkan permasalahan utama dari rendahnya kesehatan ibu dan anak pada masa perang kemerdekaan. Keempat, konsep kesehatan ibu dan anak yang merupakan salah satu program dari Menteri Kesehatan RI dalam upaya meningkatkan kesehatan ibu dan anak.

Kajian mengenai perkembangan kesehatan Indonesia telah ditulis oleh beberapa sejarawan diantaranya karya tulis Vivek Neelakantan dalam bentuk artikel jurnal yang berjudul Indonesianization of Social Medicine volume 10, nomor 1, April 2013 diterbitkan oleh jurnal Lembar Sejarah Universitas Gadjah Mada Yogyakarta. Artikel tersebut berisi tentang bagaimana Pemerintah Indonesia memulihkan kondisi kesehatan masyarakat Indonesia setelah sebelumnya dijajah oleh bangsa Belanda, Jepang, dan Belanda kembali di masa revolusi. Pada abad ke-19 yaitu pada masa penjajahan Belanda, masyarakat Indonesia hanya menerima layanan kuratif saja, dan itupun tidak merata disetiap daerah melainkan hanya di wilayah pemukiman elit kolonial saja seperti Batavia, Surabaya, dan Semarang. Sementara pada abad ke-2o dikenal istilah 'Kesehatan Sosial' yang memadukan upaya kuratif dan preventif terhadap kesehatan masyarakat. Istilah kesehatan sosial sering disamakan dengan istilah kesehatan masyarakat. Neelakantan mencatat tokoh-tokoh yang berkontribusi dalam upaya peningkatan kesehatan masyarakat Indonesia dua diantaranya ialah Poorwo Soedarmo yang merupakan ketua Lembaga Makanan Indonesia dan Dr. Johannes Leimena yang merupakan Menteri Kesehatan RI TAHUN 1946-1956. Kedua sosok tersebut juga amat berkontribusi dalam menangani permasalahan kesehatan ibu dan anak di Indonesia. Dalam artikel tersebut terdapat penjelasan mengenai permasalahan kesehatan ibu dan anak yang disebabkan karena krisis pangan, dan rendahnya layanan kesehatan ibu dan anak hingga angka mortalitas bersaing dengan angka natalitas.

\section{METODOLOGI PENELITIAN}

Metode penelitian sejarah sering disebut juga dengan metode sejarah. Metode dapat dibedakan dengan metodologi dimana metodologi merupakan "science of methods". Menurut Sartono Kartodirdjo (dalam Sjamsuddin, 2007, hlm. 14) metode dan metodologi merupakan fase yang berbeda untuk tugas yang sama. Metode merupakan cara untuk memperoleh pengetahuan, sementara metodologi merupakan cara bagaimana harus mengetahui. Dalam menulis artikel ini, peneliti menggunakan metode penelitian sejarah yang terdiri dari heuristik, kritik, dan historiografi.

Langkah awal dalam melakukan penelitian sejarah ialah mengumpulkan data atau yang biasa disebut dengan heuristik. Dalam penelitian ini, peneliti telah berhasil mengumpulkan sumber dalam bentuk hasil penelitian terdahulu, buku, ataupun dokumen dari beberapa instansi seperti Perpustakaan Universitas Pendidikan Indonesia, Perpustakaan Institut Teknologi Bandung, Badan Perpustakaan dan Arsip Jabar, Perpustakaan Dinas Kesehatan Jawa Barat, Perpustakaan Nasional Indonesia, Institut Leimena, dan Departemen Kesehatan RI.

Selanjutnya ialah kritik, kritik sumber berfungsi agar karya sejarah menjadi karya ilmiah yang betul-betul dapat 
dipertanggungjawabkan, bukan hasil dari suatu fantasi, manipulasi atau fabrikasi sejarawan (Sjamsuddin, 2007, hlm. 132). Keabsahan atau kritik sumber ini meliputi kritik eksternal dan kritik internal. Kritik eksternal yang dilakukan peneliti ialah dengan mengkaji sumber primer dengan menganalisis siapa penulis dan tahun dibuatnya tulisan tersebut, serta melihat jenis tampilan kertas dari sumber yang ditemukan. Kemudian kritik internal yang dilakukan peneliti ialah dengan membandingkan sumber dengan sumber lainnya yang relevan dengan kajian peneliti. Tujuannya untuk menentukan kredibilitas sumber agar tidak terjadi kekeliruan dalam penulisan sejarah.

Tahap selanjutnya setelah melakukan kritik sumber ialah penulisan sejarah atau historiografi. Historiografi merupakan titik puncak dari kegiatan penelitian sejarah. Langkah terakhir dan terberat sebab penulisan sejarah harus membuktikan legitimasi dirinya sebagai bentuk dari disiplin ilmiah (Puspoprojo, 1987, hlm. 1). Dalam tahap ini, peneliti selain menuangkan hasil penelitiannya peneliti juga melakukan interpretasi sejarah, eksplanasi sejarah, dan presentasi yang dilakukan dalam waktu bersamaan.

\section{HASIL PENELITIAN DAN PEMBAHASAN}

Dr. Johannes Leimena lahir di Ambon pada tanggal 6 Maret 1905. Ia merupakan putra dari pasangan Dominggus Leimena dan Elizabeth Sulilatu serta keduanya memiliki latar belakang sebagai guru. Semenjak Dr. Johannes Leimena berusia lima tahun, ayahnya Dominggus Leimena wafat dan kemudian ibunya Elizabeth Sulilatu pun menikah lagi. Semenjak pernikahan Ibu Johannes Leimena dengan ayah barunya, Johannes Leimena tidak lagi bersama ibunya melainkan ikut dengan pamannya yang bernama Jesaya Jeremias Lawalata yang berprofesi sebagai guru di Pulau Jawa. Pada tahun 1922, Dr. Johannes Leimena menjadi mahasiswa STOVIA dan pada tahun 1930 Dr. Johannes Leimena menjadi dokter di CBZ (Centrale Burgerlijke Ziekeninrichting) atau yang sekarang disebut dengan Rumah Sakit Cipto Mangunkusumo (Panitia Buku Kenangan Dr. J. Leimena, 1980, hlm. 36). Dr. Johannes Leimena pertama kali menjabat sebagai Menteri Kesehatan RI pada tahun 1946 sebagai Menteri Muda Kesehatan di bawah Menteri Kesehatan dr. Darma Setiawan pada masa kabinet Perdana Menteri Soetan Sjahrir.

Pada masa Dr. Johannes Leimena menjabat sebagai Menteri Muda Kesehatan maupun setelah menjadi Menteri Kesehatan RI, Dr. Johannes Leimena dihadapkan pada berbagai permasalahan kesehatan di Indonesia dan salah satunya ialah permasalahan angka kematian ibu dan anak yang cukup tinggi di Indonesia. Dari hasil penelusuran peneliti, pada tahun 1951 an untuk rumah sakit besar yaitu angka kematian ibu hamil (maternity death rate) mencapai $12-16 \%$ artinya terdapat 12 hingga 16 kematian Ibu per 1000 Ibu yang melahirkan, dan angka kematian bayi (infant mortality rate) mencapai $115-300 \%$ yang berarti terdapat 115-300 kematian bayi per 1000 kelahiran bayi (Leimena, 1955, hlm. 14). Jika pada catatan-catatan yang didapat dari rumah sakit besar tersebut mencapai angka mortalitas yang cukup tinggi, maka dapat dipastikan angka mortalitas ibu dan anak di luar dari pada itu lebih tinggi. Sebab menurut Geertz (dalam 
Kasmiyati, 2017) masyarakat Indonesia lebih banyak menggunakan jasa dukun bayi dalam proses kelahirannya. Tingginya angka kematian ibu dan anak di Indonesia pada tahun 1951 dapat disebabkan oleh beberapa hal. Pertama, karena sulitnya mendapatkan pelayanan kesehatan ibu dan anak di wilayah-wilayah pelosok, mengingat mayoritas penduduk Indonesia tinggal di wilayah pedesaan. Sehingga untuk penanganan kelahiran bayi dibantu oleh dukun bayi yang seringkali belum mengikuti pendidikan dukun bayi. Dari permasalahan tersebut juga dapat disimpulkan bahwa sebetulnya bidanbidan yang ada di Indonesia belum tersebar hingga kepelosok desa. Bisa saja hal tersebut dilatarbelakangi oleh rendahnya minat bidan untuk bekerja di pelosok desa. Sebab Disekuilibrium penghasilan bidan swasta dan bidan milik pemerintah yang sangat jauh. Bidan swasta mendapatkan 75 rupiah per penanganan, sementara bidan milik pemerintah mendapat 90 rupiah per bulan (Neelakantan, 2014a, hlm. 85-91).

Kedua, upaya meningkatkan kesehatan ibu dan anak juga perlu ditinjau dari sudut sosial budaya. Indonesia sebagai negara yang kaya akan budaya tidak dapat melupakan begitu saja tradisi leluhurnya. Tingginya kematian ibu dan anak ternyata juga dapat terjadi karena masyarakat Indonesia sendiri sering melakukan tradisi yang keliru seperti adanya pantangan dalam hal makanan yang dikonsumsi ibu hamil, penanganan pasca melahirkan oleh dukun beranak, dan pemberian makan non ASI kepada bayi saat bayi masih berumur satu bulan (Maas, 2004, hlm. 1-6).

Ketiga, kondisi pangan di Indonesia juga mempengaruhi tingkat kesehatan masyarakat Indonesia termasuk kesehatan
ibudananak.Kenyataannya,kondisipangan di Indonesia pasca kemerdekaan baik secara kualitatif maupun secara kuantitatif dinilai belum memuaskan, kondisi pangan seperti ini dapat mempengaruhi angka kematian bayi (infant mortality rate) dan kurangnya daya tahan tubuh terhadap serangan berbagai penyakit (Leimena, 1955, hlm. 14). Asupan bagi Ibu hamil dan anak-anak pun perlu diperhatikan untuk memastikan produktivitas sumber daya manusia Indonesia.

Berdasakan permasalahan tersebut, inilah yang membuat Dr. Johannes Leimena betul-betul memprioritaskan kesehatan ibu dan anak dengan mendirikan BKIA (Balai Kesejahteraan Ibu dan Anak) pada tahun 1951. Latar belakang program tersebut baru dapat diselenggarakan tahun 1951 disebabkan karena berbagai faktor. Faktor revolusi yang berpengaruh kepada stabilitas politik dan sosial masyarakat. Sehingga perhatian pemerintah terhadap pembangunan baru dilaksanakan selepas Indonesia menerima kedaulatan dari Belanda pada tahun 1949. Selain itu, diluar tugasnya sebagai Menteri Kesehatan, Dr. Johannes Leimena juga menjadi salah satu anggota delegasi Republik Indonesia di masa revolusi dengan Belanda. Saat menjadi anggota delegasi, Leimena diberi amanah sebagai Ketua Komisi Militer, dan Ketua Komisi Teknis masa perundingan Linggarjati (Poesponegoro \& Notosusanto, 2008, hlm. 221). Johannes Leimena juga pernah menjabat sebagai Menteri Pendidikan, Pengajaran, dan Kebudayaan Sementara pada tahun 1950. Sehingga dapat saja menghambat pelaksanaan program BKIA tersebut. Disamping itu, Dr. Johannes Leimena juga menjabat sebagai Wakil Ketua WHO Komisi Kesehatan 
RELLA ASTIANNIS DAN DIDIN SARIPUDIN

JOHANNES LEIMENA DALAM KESEHATAN IBU DAN ANAK DI INDONESIA (1946-1956)

Masyarakat tahun 1953 (Het Nieuwsblad voor Sumatra, 16 Oktober 1953); Menteri Sosial tahun 1956; Menteri Distribusi pada tahun 1960, serta menjadi Wakil Perdana Menteri masa kepemimpinan Ir. Soekarno hingga tahun 1966.

Pada awalnya BKIA dirancang untuk memberi pelatihan formal kepada para bidan dan staf medis. Namun dalam perkembangannya, BKIA kemudian mencakup penyuluhan untuk ibu, pelatihan untuk dukun beranak, imunisasi (Kasmiyati, 2017). Pelaksanaan peningkatan kesehatan ibu dan anak ini pun dibantu atas sumbangan dari lembaga internasional yaitu UNICEF. Sebesar 402.000 dolar disumbangkan dari UNICEF untuk kesehatan ibu dan anak, keperluan peningkatan gizi, dan keperluan obat-obatan di Indonesia. Beberapa negara Asia juga mendapat sumbangan yang sama dari UNICEF seperti Burma (Myanmar), India, Ceylon (Sri Lanka), Thailand, dan Afghanistan (De Preangerbode, 6 Desember 1950). Fasilitas lain yang diberikan UNICEF kepada Kementerian Kesehatan RI ialah dengan membiayai Direktur Departemen Kesehatan Ibu dan Anak yaitu Dr. Tjokroamodjo untuk melakukan studi di beberapa rumah sakit di London, Birmingham, dan Stratford. Dr. Tjokroamodjo juga diberikan pelatihan kursus pediatri (De Locomotief, 22 Juli 1953).

Upaya memberikan edukasi kepada masyarakat oleh kader kesehatan dalam menangani kurangnya pengetahuan masyarakat dalam memberikan penyuluhan kesehatan ibu dan anak diawali dengan penyelenggaraan pendidikan para tenaga kesehatan ibu dan anak. Dalam menyelenggarakan pendidikan tersebut,
Dr. Johannes Leimena kembali mendapat bantuan dana dari UNICEF sebesar 24.000 dolar untuk beasiswa bagi para tenaga kesehatan ibu dan anak (De Locomotief, 10 Juni 1950). Sehingga diharapkan dengan bertambahnya tenaga kesehatan ibu dan anak kader-kader penyuluhan kesehatan di Indonesia semakin tersebar dan pengetahuan masyarakat mengenai kesehatan ibu dan anak semakin bertambah.

Permasalahan selanjutnya yang harus segera dituntaskan oleh Dr. Johannes Leimena ialah masalah kekurangan gizi dan kalori yang dialami masyarakat Indonesia khususnya para ibu dan anak. Permasalahan tersebut diatasi dengan cara meningkatkan swasembada beras (Neelakantan, 2013, hlm. 81). Saat itu, Indonesia hanya mampu memenuhi kebutuhuan beras kepada rakyatnya. Ini memberikan gambaran betapa miskinnya Indonesia saat itu. Namun pemerintah terus berupaya melakukan swasembada beras dengan peningkatan produksi beras dilakukan dengan cara intensifikasi budidaya padi di Jawa, dan perluasan lahan tani diluar pulau Jawa. Selain itu, juga Indonesia aktif ikut serta dalam konferensi di Rangoon, Myanmar yang membahas mengenai benih berkualitas dan metode yang baik dalam bertani (Java Bode, 4 Februari 1950). Namun pada tahun 1950-an, untuk menutupi kekurangan beras pemerintah melakukan impor beras dari luar negeri. Alasan mengapa Dr. Johannes Leimena memilih untuk melakukan swasembada beras dalam mengatasi kekurangan gizi dan kalori di Indonesia ialah karena beras merupakan sumber makanan pokok rakyat Indonesia, dan dengan menggunakan beras 
distribusi makanan akan mudah merata, demi tercapainya keadilan sosial bagi rakyat Indonesia. Program swasembada beras tidak berakhir dengan baik sebab kendala koordinasi dengan Kementerian Pertanian, Transmigrasi, dan Tenaga Kerja (Neelakantan, 2013, hlm. 81).

Alternatif lain yang dimanfaatkan Dr. Johannes Leimena dalam upaya meningkatkangizimasyarakatialah dengan membentuk Lembaga Makanan Rakyat yang diketuai oleh Poorwo Soedarmo pada tahun 1951. Lembaga Makanan Rakyat membentuk Panitia Negara Perbaikan Makanan. Panitia tersebut bertugas untuk memberikan nasehat dalam masalah makanan dan kesehatan. Panitia tersebut kemudian berganti nama menjadi Dewan Bahan Makanan (Departemen Kesehatan RI, 2009b, hlm. 34). Pada tahun 1952, Poerwo Soedarmo membuat slogan 'empat sehat lima sempurna' yang diadopsi dari slogan AS yaitu 'eat the basic seven everyday'. Kampanye makanan 'empat sehat lima sempurna' ini meliputi karbohidrat, protein hewani, protein nabati, sayur-buah, dan susu. Namun karena kebanyakan masyarakat Indonesia tidak mampu menyempurnakan komposisi makanan hariannya disebabkan karena faktor ekonomi. Maka Poorwo Soedarmo mengganti slogannya dengan 'murah tapi bergizi' (Neelakanta, 2014, hlm. 56).

Setelah Dr. Johannes Leimena berupaya untuk meningkatkan kesehatan ibu dan anak melalui program BKIA, penyuluhan kesehatan, dan peningkatan gizi masyarakat. Maka hasil dari upaya tersebut memperlihatkan penuruan angka kematian ibu dan bayi dapat dilihat dari tahun 1951-1955.
Tabel 6.1

Angka Kematian Ibu dan Bayi di Indonesia Tahun 1951dan 1955

\begin{tabular}{|l|l|l|l|}
\hline Tahun & $\begin{array}{l}\text { Tingkat } \\
\text { Kematian }\end{array}$ & $\begin{array}{l}\text { Kematian } \\
\text { Bayi }\end{array}$ & $\begin{array}{l}\text { Kematian } \\
\text { Ibu }\end{array}$ \\
\hline 1951 & $22 \%$ o & $115-300 \%$ o & $12-16 \%$ o \\
\hline 1955 & $11,8 \%$ o & $97 \%$ o & $4 \%$ o \\
\hline
\end{tabular}

Sumber: Kementerian Kesehatan (dalam Biro Perantjang Negara, 1958, hlm. 201).

Perkembangan pembangunan sarana kesehatan, dari tahun 1951 sampai tahun 1954 mengalami kemajuan pesat salah satunya jumlah BKIA (Balai Kesejahteraan Ibu dan Anak) yang hanya 387 buah bertambah menjadi 1100 unit. Jumlah bidan pun bertambah yaitu pada tahun 1950 sebanyak 1.446 maka pada tahun 1954 menjadi 1.838 (Departemen Kesehatan RI, 2009b, hlm. 21-22). Dari data tersebut maka peningkatan jumlah bidan dari tahun 1950-1954 berkisar 21\%. Meskipun bertambah, nampaknya keberadaan bidan maupun dokter masih belum merata di Indonesia. Seperti di Bandung pada tahun 1954 yang belum bisa menurunkan angka kematian ibu dan anak disebabkan karena kurangnya tenaga dokter yang memberikan pelayanan kesehatan ibu dan anak (Neelakantan, 2014a, hlm. 85).

Berdasarkan permasalah tersebut maka keberadaan dukun bayi di desa dimanfaatkan untuk mengatasi kurangnya tenaga dokter dan bidan dengan cara memberikan pelatihan yang juga dilakukan oleh BKIA. Namun begitu masih ada dukun bayi yang enggan untuk mengikuti pelatihan yang diselenggarakan oleh BKIA karena alasan kekhawatiran akan bersaing dengan praktik kesehatan modern (Neelakantan, 2013, hlm. 84). 
Inovasi tersebut tentu akan menimbulkan culture shock bagi mereka yang berpegang teguh kepada tradisi. Namun, keberadaan BKIA ternyata memiliki daya tarik tersendiri bagi masyarakat desa sebab BKIA seringkali membagikan sabun, susu, dan vitamin secara gratis yang diperoleh atas kerjasama dengan UNICEF. Sehingga BKIA betul-betul menjadi garda terdepan dalam melayani kesehatan masyarakat pedesaan (Baha'Uddin, 2008, hlm. 8).

Peningkatan gizi masyarakat Indonesia, khususnya ibu dan anak juga mengalami peningkatan walaupun, program swasembada beras yang dicanangkan oleh Dr. Johannes Leimena untuk meningkatkan gizi masyarakat Indonesia kenyataannya tidak dapat memenuhi kebutuhan pokokseluruh rakyat Indonesia. Hal ini disebabkan karena pertama, koordinasi yang tidak baik antara Kementerian Kesehatan, Departemen Kesehatan Provinsi dan Pemerintah Daerah (Neelakantan, 2014, hlm. 6o-68). Kedua, jumlah penduduk terus meningkat di mana setiap tahunnya meningkat sebanyak $2 \%$. Upaya swasembada beras yang meskipun gagal pada tahun 1951, namun upaya ini pada awalnya dapat membantu mengurangi angka mortalitas ibu dan anak hingga penduduk Indonesia bertambah pada tahun berikutnya. Meski begitu pemerintah tetap melakukan pendistribusian beras kepada masyarakat miskin. Hal ini didasarkan pada pernyataan dari Dr. Johannes Leimena bahwa "Kemiskinan penduduk merupakan hambatan utama untuk mencapai peningkatan gizi masyarakat. Oleh karena itu, perlu terlebih dahulu memperbaiki kondisi kesejahteraan, pendidikan dan sosial penduduk sebelum dilakukan perbaikan di bidang gizi” (Java Bode, 24 Juni 1953).

Kegagalan koordinasi Kementerian Kesehatan, Departemen Kesehatan Provinsi, dan Pemerintah Daerah berdampak pada kegagalan swasembada beras di Indonesia. Namun, kerjasama antara Kementerian Kesehatan RI dengan lembaga internasional seperti WHO dan UNICEF, serta Menteri Pendidikan RI semakin erat. Ini berdampak pada meningkatnya kesadaran masyarakat akan pentingnya memenuhi gizi harian yang seimbang. Sehingga masyarakat Indonesia meningkat sejumlah $2 \%$ setiap tahunnya.

Lembaga Internasional WHO membantu mendistribusikan dana dari UNICEF untuk program peningkatan gizi di Indonesia. WHO pun mendatangkan dua ahli gizi nya untuk membantu perkembangan fasilitas pelatihan Lembaga Makanan Rakyat di Jakarta (Het Nieuwsblad voor Sumatra, 3 September 1952). Lembaga makanan di Jakarta pada tahun 1954, membuka pelatihan bagi para ibu, dan organisasi wanita. Dalam kursus tersebut pemerintah juga memperkenalkan slogan 'makan murah tetapi sehat' (Het Nieuwsblad voor Sumatra, 1 Februari 1954). Kemudian untuk menyukseskan program pelatihan gizi tersebut Menteri Kesehatan RI bekerjasama dengan Menteri Pendidikan RI yaitu dengan mengikutsertakan para tenaga pendidik atau guru. Hal ini didasarkan pada pertimbangan bahwa sebetulnya peran guru sama dengan bidan yang merupakan kerangka kerja terpenting dalam upaya peningkatan kesehatan ibu dan anak di Indonesia. Kementerian Pendidikan sudah mempertimbangkan hal tersebut sehingga diharapkan dapat meningkatkan 
kesadaran akan pola makan yang baik di kalangan para pelajar Indonesia (Java Bode, 22 Januari 1954).

Dilibatkannya organisasi wanita dan guru merupakan strategi yang tepat sebab peran wanita dalam keluarga memiliki kedudukan yang penting sebagai ibu. Seorang ibu berperan untuk mengurus kebutuhan rumah tangga termasuk membimbing putra-putrinya agar menjadi manusia yang sehat jasmani dan rohani. Sementara guru berperan untuk mendidik, mengajar, dan melatih siswa-siswanya dalam hal ini mengedukasi siswanya untuk dapat memperhatikan asupan makanan yang baik untuk dikonsumsi.

Kebudayaan yang tercipta dalam masyarakat tidak terlepas dari adanya interaksi atau aktifitas sesama anggota masyarakatnya. sejarah muncul dan perkembangan Angklung Gubrag.

\section{SIMPULAN}

Balai Kesejahteraan Ibu dan Anak sebagai layanan kesehatan primer dalam menanggulangi permasalahan kesehatan ibu dan anak serta masyarakat desa mampu menurunkan angka kematian ibu dan anak di Indonesia. Keberhasilan tersebut ditunjang oleh beberapa hal diantaranya: Sistem perencanaan yang tepat yaitu dengan didirikan disetiap daerah di Indonesia sehingga meminimalisir kendala keterjangkauan. Program edukasi kepada masyarakat menjadi hal yang tidak kalah penting dari pada sekedar memberi pelayanan kesehatan sehingga meningkatkan kesadaran dan menambah pengetahuan masyarakat khususnya mengenai kesehatan ibu dan anak. Kerjasama dengan beberapa lembaga seperti UNICEF, Kementerian Pendidikan,
Kementerian Pertanian, Transmigrasi, dan Tenaga Kerja yang membuat program peningkatan kesehatan ibu dan anak berjalan dengan baik. Walaupun kendala swasembada beras dalam upaya meningkatkan gizi masyarakat Indonesia gagal karena gagalnya koordinasi dengan Kementerian Pertanian, Transmigrasi, dan Tenaga Kerja sehingga Indonesia harus mengimpor beras. Hal tersebut terjadi karena sebetulnya program swasembada beras ini dapat dikatakan berhasil dalam upaya meningkatkan gizi masyarakat sehingga jumlah penduduk Indonesia bertambah $2 \%$ justru karena pertambahan penduduk tersebut akhirnya Indonesia tidak dapat melaksanakan swasembada beras kembali Alat musik Angklung Gubrag sudah digunakan sejak lama oleh masyarakat Cigudeg sebagai media ritual dalam upacara Seren Taun yang bertuu

\section{REFERENSI}

Abdurahman, D. (2007). Metodologi Penelitian Sejarah. Yogyakarta: ArRuzz Media.

Baha'Uddin. (2006). Politik Etis dan Pelayanan Kesehatan Masyarakat di Jawa Pada Awal Abad XX. [Makalah]. Jakarta: Dipresentasikan pada konferensi Nasional Sejarah VIII. Diakses dari http://www.academia. edu/4435394/POLITIK_ETIS_ DAN_PELAYANAN_KESEHATAN_ MASYARAKAT_DI_JAWA_PADA_ AWAL_ABAD_XX

Baha'Uddin. (2008). Politik Kesehatan Masyarakat di Indonesia Pasca Kemerdekaan. Yogyakarta: Universitas Gadjah Mada. [Online]. Diakses dari https://www.academia. edu/20814025/Politik_Kesehatan_ 
Masyarakat_di_Indonesia_Pasca_ Kemerdekaan

Biro Perantjang Negara. (1958). Garisgaris Besar Rentjana Pembangunan Lima Tahun 1956-196o. Tanpa Kota: Biro Perantjan Negara.

Cribb, R. (2010). Para Jago Kaum Revolusioner 1945-1949. Jakarta: Masup Jakarta.

Cunningham, F. (2002). Theories of Democracy: A Critical Introduction. New York: Routledge.

De Locomotief. (1953, 22 Juli). "Dr Tjokroatmodjo terug in Indonesië". De Locomotief.

Departemen Kesehatan RI. (2009a). Sejarah Kesehatan Nasional Indonesia Jilid 1. Jakarta: Departemen Kesehatan RI.

Departemen Kesehatan RI. (2009b). Sejarah Kesehatan Nasional Indonesia Jilid 2. Jakarta: Departemen Kesehatan RI.

Gottschalk, L. (2008). Mengerti sejarah. Jakarta: Universitas Indonesia Press

Java Bode. (1953, 24 Juni). "Armoede". Java Bode, hlm. 1.

Ismaun. (2005). Pengantar Belajar Sejarah sebagai Ilmu dan Wahana Pendidikan. Bandung: $\mathrm{H}$ i s t o r i a Utamra Press.

Ismaun. (2005). Sejarah Sebagai Ilmu. Bandung: Historia Utama Press

Java Bode. (1954, 22 Januari). "Voorlichting over juiste voeding der bevolking”. Java Bode, hlm. 2.

Kasmiyati. (2017). Dari Yogyakarta untuk Indonesia, Badan Kesehatan Ibu dan Anak 1952-1969. [Online]. Diakses dari https://histma.fib.ugm. ac.id/2017/06/13/49/.
Kuntowijoyo. (1995). Pengantar Ilmu Sejarah. Yogyakarta: Bentang Budaya. Langlois, CH.V., \& Seignobos. CH. (2015) Introduction to the Study of History. Terjemahan Supriyanto Abdullah. Yogyakarta: Indoliterasi.

Leimena, J. (1955). Kesehatan Rakjat di Indonesia: Pandangan dan Planning. Jakarta-Band ung-SemarangSurabaya: N. V. vh G.C. T. Van Dorp \& Co.

Maas, L T. (2004). Kesehatan Ibu dan Anak: Persepsi Budaya dan Dampak Kesehatannya. Medan: Universitas Sumatera Utara. Diakses dari http:// library.usu.ac.id/download/fkm/ fkm\%2olinda2.pdf.

Neelakantan, V. (2013). Indonesianization of Social Medicine. Yogyakarta: Universitas Gadjah Mada. [Jurnal]. Lembar Sejarah, Vol. 10, No.1, hlm. 7486.

Neelakantan, V. (2014). Health and Medicine in Soekarno Era Indonesia: Social Medicine, Public Health and Medical Education 1949 to 1967. [Tesis]. Sydney: University of Sydney.

Panitya Buku Kenangan Dr. J. Leimena (1980). Kewarganegaraan yang Bertanggungjawab - mengenang Dr. J. Leimena. Jakarta: BPK Gunung Mulia.

Poesponegoro, M. D., \& Notosusanto, N. (2008). Sejarah Nasional Indonesia IV: Zaman Jepang dan Zaman Republik Indonesia (+- 1942-1998). Jakarta: Balai Pustaka.

Priyadi, S. (2012). Metode Penelitian Pendidikan Sejarah. Yogyakarta: Ombak.

Ricklefs, M.C. (1991). Sejarah Indonesia Modern. Yogyakarta: Gajah Mada University Press. 
Volume 7, No.2, Oktober 2018

Sarinah. (2016). Ilmu Sosial Budaya Dasar

(Di Perguruan Tinggi). Yogyakarta: Deepublish.

Sjamsuddin, H. (2007). Metodologi Sejarah. Yogyakarta: Ombak.
Wadlaw, G. (2006). Political Terrosim. Jakarta: Cambridge University Press. Wiharyanto, A. K. (2011). Sejarah Indonesia: Dari Proklamasi sampai Pemilu 2009. Yogyakarta: Universitas Sanata Dharma. 